RESEARCH PAPER

\title{
Tobacco industry efforts to present ventilation as an alternative to smoke-free environments in North America
}

\author{
J Drope, S A Bialous, S A Glantz
}

Tobacco Control 2004;13(Suppl I):i41-i47. doi: 10.1136/tc.2003.004101

See end of article for authors' affiliations

Correspondence to: Stanton A Glantz, PhD, Box 1390, University of California, San Francisco, CA 94143-1390, USA; glantz@medicine.ucsf.edu
Objective: To describe how the tobacco industry developed a network of consultants to promote ventilation as a "solution" to secondhand smoke (SHS) in the USA.

Methods: Analysis of previously secret tobacco industry documents.

Results: As with its other strategies to undermine the passage of clean indoor legislation and regulations, the tobacco industry used consultants who represented themselves as independent but who were promoting the industry's ventilation "solution" strategies under close, but generally undisclosed, industry supervision. The nature of the industry's use of ventilation consultants evolved over time. In the 1980s, the industry used them in an effort to steer the concerns about indoor air quality away from secondhand smoke, saying SHS was an insignificant component of a much larger problem of indoor air quality and inadequate ventilation. By the 1990s, the industry and its consultants were maintaining that adequate ventilation could easily accommodate "moderate smoking". The consultants carried the ventilation message to businesses, particularly the hospitality business, and to local and national and international regulatory and legislative bodies.

Conclusion: While the tobacco industry and its consultants have gone to considerable lengths to promote the tobacco industry's ventilation "solution", this strategy has had limited success in the USA, probably because, in the end, it is simpler, cheaper, and healthier to end smoking. Tobacco control advocates need to continue to educate policymakers about this fact, particularly in regions where this strategy has been more effective.
S moke-free workplaces reduce cigarette consumption by about $29 \%$ through a combination of increased cessation and reduced consumption among continuing smokers. ${ }^{1}$ The tobacco industry identified this serious threat to its profits in the 1970s. ${ }^{23}$ By 1992, Philip Morris (PM) estimated that smoke-free workplaces would increase quit rates and reduce cigarette consumption by $11-15 \%{ }^{4}$ In 1988 PM recognised that as many "people spend most of their smoking hours in a workplace environment, and widespread work$\overline{\text { place }}$ restrictions would severely affect the industry" [underlined by hand in the original.$^{5}$ The industry also realised that opposing any regulation of smoking in workplaces and public places was politically untenable, ${ }^{6}$ so it sought "solutions" that would continue to permit smoking with as few restrictions as possible.

Key elements of the tobacco industry's efforts to oppose smoke-free areas included claims that the problem of secondhand smoke (SHS) was insignificant when compared to other indoor air pollutants and that it could be solved by ventilation. As with its efforts to discredit the scientific evidence that SHS was dangerous, ${ }^{7-16}$ the industry developed a network of ventilation "experts". This paper describes five of the more prominent "experts" in North America, who were often used in other regions. The tobacco industry used these "experts" to join committees, attend conferences, influence ventilation standards, and promote ventilation solutions to workplaces, hospitality establishments, legislators, and the general public, often without disclosing their financial relationship with the industry.

\section{METHODS}

We analysed tobacco industry documents available on the internet as a result of tobacco litigation during the 1990s. This included the PM, Brown and Williamson, RJ Reynolds,
Lorillard, the Tobacco Institute (TI), and the UCSF Legacy Tobacco Documents Library web sites. Searches were conducted from November 2001 to November 2002. We also used British American Tobacco documents from the Guildford depository identified in a manual search of the documents conducted in November 2001. Although promoting ventilation is a tobacco industry wide effort, most of the documents referred to in this paper come from PM.

\section{RESULTS}

The tobacco industry invested considerable resources to develop and disseminate its "ventilation solution". As Matt Winokur, director of PM USA worldwide regulatory affairs suggested in a 1990 memo to PM's Jack Nelson:

Longer term, we want also to be able to identify a number of experts in the field of ventilation technology. By way of analogy, these experts and their firms would do for the ventilation solution issue what Gray Robertson ${ }^{12}$ has been able to accomplish for the sick building issue. But while Robertson has focused on identifying the 'problem,' what

\footnotetext{
Abbreviations: ACVA, Air Conditioning \& Ventilation Analysis; ASHRAE, American Society of Heating, Refrigeration, and Air Conditioning Engineers; BCIA, Business Council on Indoor Air; CIAR, Center for Indoor Air Research; ETS, environmental tobacco smoke; HBI, Healthy Building International; HVAC, heating ventilation and air conditioning; $I A Q$, indoor air quality; $F A C T$, filtered air control technology; ORNL, Oak Ridge National Laboratory; OSHA, Occupational Safety and Health Association; PM, Philip Morris; RSP, respirable suspended particulate; SHS, secondhand smoke; TDS\&A, Theodore D Sterling and Associates; TI, Tobacco Institute; VTS, ventilation technology systems
} 
we propose is to identify people who we could call on to provide the solution to the problem. ${ }^{17}$

Winokur further proposed creating "an 'industry' of ventilation consultants which could pitch ventilation as the solution to a host of indoor air quality (IAQ) problems.,"17

In the 1990s the tobacco industry began to research and invest in different kinds of ventilation systems that might be useful in reducing SHS while having little or no effect on people's smoking behaviour. ${ }^{18}{ }^{19}$ For example, PM was particularly interested in displacement ventilation. ${ }^{20-23}$ In 1990, PM provided $\$ 1$ million to James Woods, a professor at the Virginia Polytechnic Institute, to compare a displacement ventilation system called filtered air control technology (FACT) with conventional ventilation systems. The FACT system involved a low velocity floor dispersion delivery method and air filtration system. ${ }^{24}$ The FACT system failed; according to an industry assessment, "the level for nicotine [in the air with the FACT system operating] would be such that smoking in the indoor environment may not be possible." ${ }^{23}$ Despite this internal recognition of failure, in $1991 \mathrm{PM}$ and its public relations firm, Burson-Marsteller, issued news releases saying "Early experience shows the FACT concept reduces airborne materials produced from tobacco smoke to one-tenth the amount in an identical room with conventional ventilation" 25 and "if operated according to manufacturer's standards, the components and concept will improve indoor air quality and can be a tool to prevent Sick Building Syndrome." ${ }^{26}$ Neither press release mentioned nicotine or claimed that the system reduced SHS to a level where there would not be adverse health effects.

The tobacco industry had parallel strategies of identifying contaminants other than SHS as creating IAQ problems as well as offering ventilation-as opposed to simply creating smoke-free environments-as the solution.

\section{ACVA Atlantic/Healthy Buildings International}

During the late 1970s and early 1980s, efforts to restrict smoking concentrated on creating designated non-smoking areas in workplaces, public places, and, to a lesser extent, restaurants. ${ }^{27}$ This situation started to change after the 1986 US Surgeon General's first report on involuntary smoking concluded that: "The simple separation of smokers and nonsmokers within the same air space may reduce, but does not eliminate exposure of nonsmokers to [SHS]". ${ }^{28}$ The industry response was to continue to challenge that SHS was dangerous to health, and to affirm that SHS was not a substantial contributor to IAQ problems.

In 1986, the now-extinct TI hired a small company called ACVA Atlantic (Air Conditioning \& Ventilation Analysis) as a consultant. $^{29}$ The organisation's CEO, Gray Robertson, became the main spokesperson for the tobacco industry message that SHS was not the problem, rather that it was "sick" buildings. ${ }^{30-32}$ (The term "sick building syndrome" was coined in the mid 1980s to describe modern, airtight office buildings created for energy efficiency that caused ill health. ${ }^{33}$ ) In addition to working as an expert on IAQ and sick building syndrome, Robertson participated in media tours and travelled the world spreading the industry's message. ${ }^{32}{ }^{34-37}$

To deal with the growing public awareness of SHS as an important indoor pollutant, PM's "Indoor Air Quality: Alternative Strategy" identified the need to retain "a firstrate PR firm". ${ }^{29}$ The TI hired public relations firm FleishmanHillard to work with ACVA Atlantic, ${ }^{38}$ but the link with the TI was to be hidden. Robertson expressed this need in a letter to PM vice president of corporate affairs Guy Smith:
It was with great trepidation, therefore that we negotiated with the Tobacco Institute to start this last year's media tour. Many felt that the media would quickly identify a link between ACVA and the tobacco industry that would jeopardize my future testimony on legislative issues. However, despite massive media attention, to date no one has identified such a link, which reflects well on the tact and diplomacy of our public relations firm of Fleishman Hillard. ${ }^{32}$

Robertson and his employees conducted surveys on IAQ funded by the tobacco industry and used these studies to influence legislation and publish in what they termed "scientific or quasi-scientific" journals and professional magazines. ${ }^{39}$ They also delivered papers at conferences and Building Owners and Managers Association meetings, appeared at legislative hearings across the USA, responded to scientific articles on the problem of SHS, and offered formal comments to government agencies investigating SHS. $^{34} 38$ 40-44

In 1989 Robertson renamed his company Healthy Buildings International (HBI) and expanded the business both in the USA and internationally with continued financing by the tobacco industry. ${ }^{41}{ }^{42}$ Offices were opened in Australia, ${ }^{45}$ Spain, ${ }^{46}$ the UK, Canada, ${ }^{35}$ and Kuala Lumpur. ${ }^{47}$ HBI also did work for British American Tobacco and PM International in several Latin American and Asian countries, as part of the industry's worldwide environmental tobacco smoke (ETS) consultancy programmes. ${ }^{14}{ }^{16} 47-49$ The international work HBI did for the industry was similar to its work in the USA: media tours, presentations at scientific meetings, and development of IAQ and sick building research to divert attention from the link between SHS and IAQ. ${ }^{50-54} \mathrm{HBI}$ also published magazines in the USA, ${ }^{55}$ Sweden, Germany, France, Italy, Venezuela, and Belgium. ${ }^{35}$

By 1988, Robertson was also working on the tobacco industry's ventilation "solution". He became a fully participating member of the Business Council on Indoor Air (BCIA) for the TI. ${ }^{43}{ }^{56}$ BCIA is a trade group that promotes ventilation or a building systems approach to IAQ rather than source control. Robertson was on the board of directors ${ }^{57}$ and was a member of the Legislative Affairs Work Group. ${ }^{58}$ A 1988 TI document on public smoking programmes claimed that it influenced BCIA through their consultants who were members and through close relations with its executive director, Paul Cammer. The tobacco industry hid its ties with the consultants so that the credibility of BCIA would not be questioned. ${ }^{42}$

ACVA/HBI's financial relationship to the tobacco industry was not disclosed in its publications and consultations with businesses. In 1992, in response to a civil suit by a former HBI employee, Robertson admitted that HBI accepted hundreds of thousands of dollars in fees annually from the tobacco industry to do the work described above. ${ }^{59}$ The case was settled out of court.

\section{Roger Jenkins and the Oak Ridge National Laboratory} Another strategy to minimise the problem of exposure to SHS was to fund studies that would not only question risk assessment methods, but would attempt to prove that levels of exposure have been exaggerated. Dr Roger Jenkins, a chemist at the Oak Ridge National Laboratory (ORNL), was instrumental in this strategy. Jenkins has a long history of working for the tobacco industry. ${ }^{60}$ Starting in the mid 1980s, Jenkins conducted "special project" research with RJ Reynolds scientists ${ }^{61-63}$ and was funded by the industry's now-extinct Center for Indoor Air Research (CIAR) for many projects and more recently by PM's External Research Program. ${ }^{11}$ 64-68 
Jenkins' "16 Cities" study, funded by the CIAR, and conducted in 1993-94, ${ }^{69}$ recruited subjects from 16 US cities to measure personal exposure to SHS and other air pollutants at work and at home. His conclusions were that the home appeared to be a greater source of SHS exposure than the workplace and that Occupational Safety and Health Association (OSHA) exposure estimates were much higher than exposure levels in his "16 cities" study. ${ }^{70}$ There were serious biases in the way that the sample was selected that led to low exposure values being reported. ${ }^{7-73}$ Nonetheless, the results of the study are widely quoted by industry allies in legislative and regulatory hearings to justify the view that smoking is not a major source of indoor air pollution. ${ }^{74}$

By the late 1990s, Jenkins' shifted focus slightly to claim that if appropriate ventilation was provided, exposure to harmful effects of SHS was negligible. He argued that displacement ventilation, the same type as the FACT system, ${ }^{24}$ could be a solution to SHS. In particular, he studied a system installed in the Black Dog Pub in Toronto, Canada. This system involved a one-pass displacement ventilation system that takes air from the non-smoking area to the smoking area through two open passages and windows, supplemented with air blowing in to the smoking section, and then exhausts the air outside. ${ }^{75}{ }^{76}$ Jenkins $e t ~ a l^{76}$ reported that this system could be leased for $\$ 20000$ over a five year lease. This cost does not include the increased energy costs due to the fact that the air is not recirculated. Additionally, Jenkins et $a l^{76}$ measured SHS in the cashier station in the non-smoking sections of the pub and behind the bar at the Black Dog Pub as well as in non-smoking dining areas of three smoke-free venues. They concluded that ventilation techniques for restaurants/pubs with separate smoking and non-smoking areas are capable of achieving SHS concentrations in the non-smoking area that are "not statistically significantly different" from those of similar facilities that prohibit smoking outright..$^{75}$ The paper did not report the respirable suspended particulate (RSP) measurements taken in the smoking area of the pub, why there was no reporting on data from the non-smoking seating area, or on workers' exposure to SHS.

Subsequently, Repace ${ }^{77}$ investigated the pollution levels in the smoking section of the Black Dog Pub (Repace, personal communication, 2003) and found high levels of both RSP and particulate PAH (PPAH) carcinogens. Repace found that the average RSP level was $199 \mathrm{ug} / \mathrm{m}^{3}$, nine times the outdoor RSP level of $22 \mathrm{ug} / \mathrm{m}^{3}$, and average PPAH of $152 \mathrm{ng} / \mathrm{m}^{3}, 19$ times the outdoor average of $8 \mathrm{ng} / \mathrm{m}^{3}$. The levels of RSP that Jenkins et al reported in the non-smoking section (located at the cashier station) averaged $24,2 \mathrm{l}$, and $49 \mathrm{mg} / \mathrm{m}^{3}$, comparable to Repace's outdoor levels. The presentation of the results in Jenkins et al's paper ${ }^{76}$ obscures the tobacco industry's role in supporting and publicising this study. The paper reports that the study was sponsored by the Hotel Association of Canada. This association receives funding from the tobacco industry's Courtesy of Choice programme in Canada. ${ }^{6}$ The paper was published in the journal Regulatory Toxicology and Pharmacology ${ }^{76}$ which is financed by several corporations including RJ Reynolds. ${ }^{78}$

The tobacco industry and its allies use the Black Dog Pub study as evidence that ventilation "solves" the SHS problem in hospitality venues so that creating smoke-free environments is not necessary. Both the Canadian Restaurant and Foodservices Association and the Ontario Hotel and Motel Association promoted the results of the Black Dog Pub study to convince people there is a ventilation "solution" to SHS. ${ }^{79-82}$ It has also been cited in presentations to municipal councils and public consultations meetings by groups opposing bylaws restricting smoking. ${ }^{83-85}$ In addition, the study is frequently represented as being the work of the US Department of Energy, since this department also has contracts with ORNL, although Jenkins tobacco industry funded research is not endorsed by the US Department of Energy or any other government agency. ${ }^{84}$

\section{Theodore and Elia Sterling}

Dr Theodore Sterling and his son Elia helped the tobacco industry pioneer its ventilation strategy. Theodore Sterling, a retired professor at Simon Fraser University in British Columbia, Canada, also ran Theodore D Sterling and Associates (TDS\&A), a private consulting firm. Between 1973 and 1990 TDS\&A received over \$5 million in funding through the now extinct Council for Tobacco Research special projects, an industry programme to discredit scientific findings about the health dangers of smoking and of SHS. ${ }^{108687}$

In 1993 the industry decided to reorient Sterling's work from attacking the science linking SHS with disease to presenting ventilation as a way to deal with SHS. In 1994, the industry law firm Shook, Hardy \& Bacon evaluated the umbrella grant that TDS\&A had with PM since 1973 and concluded that a new strategic direction was needed to counter growing awareness that SHS exposure was widespread ${ }^{88}{ }^{89}$ The lawyers suggested that Sterling focus on IAQ, building science and SHS research issues. The Sterlings had published earlier on issues related to sick building syndrome and ventilation when focusing on the problem, so refocusing on the solution fit within their work..$^{90-92}$ One of the projects involved providing scientific support to the $3 \mathrm{M}$ Corporation who believed they had the technology to provide a cost effective filter to remove SHS. This project also proposed looking at whether restaurant and bar workers had elevated risks for cancer or other diseases. ${ }^{88}$ While the authors could not determine if this project was implemented and published, in 1998 Elia Sterling and Wilfred Rosenbaum released a report $^{93}$ arguing that the ventilation systems being proposed in the Hospitality Industry of British Columbia's "Indoor Air Quality Ventilation Plan" would lead to acceptable levels of lung cancer in hospitality workers even though it accepted very high levels of RSP (as much as $300 \mu \mathrm{g} / \mathrm{m}^{3}$ ). Sterling also cited his more than 100 articles as evidence against the implementation of the British Columbia Workers' Compensation Board regulations to stop smoking in all workplaces. ${ }^{94}$

Elia Sterling has played an important role for the tobacco industry in trying to influence the development of the American Society of Heating, Refrigeration, and Air Conditioning Engineer's (ASHRAE) standard 62, ventilation for acceptable indoor air quality, in a way that would codify the industry's position that ventilation was an appropriate strategy for dealing with SHS. ${ }^{95}$ Despite tobacco industry efforts, the current standard 62-1999 specifies ventilation standards assuming no smoking. (Due to a drafting error, it did not apply to casinos, bars, and cocktail lounges. As of October, 2003, an amendment had been proposed to close this loophole but it had not yet been incorporated into the standard.) Since ASHRAE is an international association, its decision may reach other regions of the world besides North America. In fact, there is evidence of the industry attempting to use the ASHRAE standard 62 in Latin America ${ }^{48}$ as well as the tobacco industry's earlier efforts to influence the development of international IAQ standards at the International Organization for Standardization. ${ }^{96}$

\section{George Benda and the Chelsea Group}

By the 1990s, the evidence demonstrating the dangers of SHS had accumulated to the point that even the tobacco industry recognised that simply opposing any restrictions on smoking 
was such an extreme position that it would have no credibility. ${ }^{6} \mathrm{PM}$ readjusted its ultimate objective to "ensure reasonable accommodation of smokers to protect long-term viability of $\mathrm{PM}^{\prime \prime} .^{97}$ The end result was the creation of several programmes, directly or indirectly funded by the tobacco industry, meant to accommodate smokers, mainly in hospitality venues, such as the PM USA "Accommodation Program" and "atmospherePLUS". ${ }^{48}$

Further, the tobacco industry started to develop more programmes and alliances focusing on ventilation as a solution to "accommodate" both smokers and non-smokers. For example, in November 2002, PM's Options web site presented it as "a program designed to help business owners that accommodate smoking find effective, practical ways to reduce secondhand smoke and create a more comfortable environment for customers and employees." ${ }^{\prime 98}$ Through these programmes the tobacco industry recognised that some people were "bothered" by SHS and accepted non-smoking and smoking sections in order to guarantee that smoking would still be permitted in at least part of the venue. In 2003, PM closed the Options web page, but continued to promote good ventilation systems that would purportedly prevent the smoke from penetrating the non-smoking section (while continuing to be careful to avoid claiming that ventilation would address the heath dangers of secondhand smoke). ${ }^{99}$

One example of the many ways the tobacco industry promoted ventilation as an alternative to smoke-free policies is the relationship between PM and the Chelsea Group. In 1993, PM hired the Chelsea Group's CEO George Benda to recommend methods for accommodating both smokers and non-smokers as part of its Accommodation Program in the USA $^{100}$ and to promote "engineering options" in an effort to show that ventilation is a cost effective option that companies should pursue for economic benefit. ${ }^{101}{ }^{102}$ Since then, the Chelsea Group has taken a leading role in spreading the industry's message directly to the hospitality industry. ${ }^{6}$ For example, the Chelsea Group runs the INvironment Hospitality Industry Program, which provides consulting services and materials for hospitality organizations that "do not want to ban smoking". A toll-free INvironment Hotline was provided on the PM Options website. ${ }^{98}{ }^{101}$ Benda and the Chelsea Group frequently comment in professional standard setting and regulatory hearings when smoke-free measures are being considered..$^{74}{ }^{95} 103$ They also appear at hospitality industry conventions and trade shows and provide "expert" testimony to oppose smoke-free ordinances in many US cities. For example, Benda promoted ventilation solutions in Honolulu, Hawaii, Mesa City Arizona, and Anchorage Alaska. ${ }^{100} 104105$

\section{9 and beyond}

A 1999 PM memo on the ETS/VTS (ventilation technology systems) ${ }^{106}$ planning process by a PM engineer working on IAQ issues suggested plans for ETS/VTS for 1999 and beyond, which essentially continued the past strategies: "Also, my discussions with her [Cathy Ellis, a senior PM scientist] indicate her desire for us to develop partnerships with academic institutions for research. The scope of our research efforts encompass both ventilation technology and exposure measurement but does not extend into health related issues. [emphasis added]." 107

In a 1999 proposal to Ellis the PM engineer proposed the formation of what would appear to be a post-CIAR organisation called the "Corporation to Support Indoor Air Research" that would be funded entirely by PM for approximately \$6 million per year to focus on research on IAQ and ETS, including ventilation technology. ${ }^{108}$ They would then "communicate these findings to scientists, regulators and science and engineering advisory boards" 108 and would give "regulators greater flexibility to deal with indoor air issues". ${ }^{108}$ The documents do not indicate whether this proposal was implemented.

Despite these efforts, PM recognised that it had made little progress through its ventilation strategy in the USA. Its 1999 National Ventilation Program Execution Plan ${ }^{109}$ concluded the heating ventilation and air conditioning (HVAC) industry still did not consider accommodation a business opportunity. PM considered this situation a supply/demand "disconnect" that needed a facilitator to bring the HVAC and hospitality industries together. PM was still seeking a way to "educate" HVAC providers on ventilation design applications specific to accommodation of smoking. PM still wanted to make accommodation a "marketable product and a niche business opportunity for the HVAC industry" that would support national and state hospitality programs. ${ }^{109}$

\section{DISCUSSION}

The tobacco industry has developed a complex and dynamic ventilation strategy, but several elements have remained constant. As elsewhere, ${ }^{7-16}$ the industry uses "experts" to create science and to act as messengers to different audiences. In the USA, in addition to its network of consultants, the tobacco industry's ventilation strategy has used third party allies to lead public opposition to smoke-free policies, dismiss the risks of exposure to SHS, promote ventilation "solutions" to SHS, and lobby for a separate ventilation standards for the hospitality industry. These allies include the National Energy Management Institute, ${ }^{42} 95$ 110-112 the Sheet Metal Workers Union, ${ }^{42} 95$ and the Hospitality Coalition for Indoor Air. ${ }^{113-115}$

In 1988, one PM ETS strategy document explained that: "the fundamental reasoning behind the IAQ plan was to push this technology in the hope that a self-sustaining commercial niche could be created. The burden of pushing the 'IAQ' issue would then fall to the companies involved, who would have a commercial reason for doing so."116 According to this document, this goal had not yet been achieved, making it a problem that needed immediate attention. Some solutions were "to subsidize the creation of ACVA licensees" ${ }^{\prime 55}$ and identify and support other potential ventilation companies "(with technical and marketing expertise) until they can stand alone". ${ }^{116}$ The 1988 PM ventilation strategy ${ }^{116}$ and the 1999 PM ventilation plan ${ }^{109}$

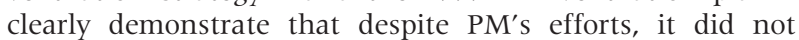
succeed, for the most part, in convincing the HVAC business to protect the tobacco industry's interests, at least in the USA.

In some instances, the industry paid for ventilation systems in establishments so that they could serve as models for other venues, ${ }^{117118}$ and a 1988 PM paper on IAQ programmes revealed that, at least at that time, PM provided "grants to some organizations for purchase of ventilation equipment". ${ }^{119}$

The tobacco industry has yet to admit the extensive harmful effects of exposure to SHS. Furthermore, neither the ventilation consultants nor the tobacco industry make statements that ventilation systems control the health dangers of SHS. Therefore, the industry and its consultants also do not recognise that the levels of ventilation required to control the health risks of SHS are economically unfeasible. $^{120} 121$ Notes from a 1999 PM Options seminar explicitly stated: "The content presented in this workshop does not purport to address health effects attributed to smoking."102 PM adds this disclaimer to their recommendations promoting ventilation. ${ }^{98}$ The industry is careful to limit their claims to ones that no smoke leaks from smoking to non-smoking sections, that air cleaners minimise visible smoke and odour, and that customers are satisfied. ${ }^{122}$ Indeed, the tobacco industry focuses their strategy on customer perception 


\section{What this paper adds}

Opponents of smoke-free policies, particularly in the hospitality industry, present ventilation as a "solution" to the problem of secondhand smoke. The tobacco industry has a well established history of using hospitality groups to promote its interests and has also worked to influence ventilation standards.

As with its efforts to discredit the scientific evidence that secondhand smoke was dangerous, the industry developed a network of ventilation "experts" to promote its position that smoke-free environments were not necessary, often without disclosing the financial relationship between these experts and the industry. This paper describes how this network was developed and evolved over time. Despite considerable investment of resources, this strategy has had limited success in the USA, probably because, in the end, it is simpler, cheaper, and healthier to end smoking. The tobacco industry, however, has continued to use the strategy in other parts of the world with more success.

because industry research indicates that if people cannot see or smell the smoke, they feel they are not exposed to a contaminant. The industry continues to press ventilation standard setting bodies (such as ASHRAE) for an odour-not a health-standard..$^{95}{ }^{123}$

The scope of this paper only allowed for the authors to touch on the activities of five prominent industry ventilation "experts" in North America, but there is documentary evidence that others exist around the world. PM's 1998 Worldwide Accommodation Plan ${ }^{124}$ clearly outlines the company's continuation of its ventilation strategy. HBI, headquartered in Sydney Australia, still works for the tobacco industry, ${ }^{45} 123$ programmes such as "Courtesy of Choice" and "Living in Harmony" and Traditional Hospitality 48125126 indicate that ventilation is continuing, if not growing, as an industry strategy to oppose clean indoor air measures.

While the ventilation strategy has had limited success in North America, the tobacco industry has been more successful with it in other parts of the world. For example, in the UK the government has worked with the tobacco industry's allies in the hospitality industry to promote a "Public Places Charter" that does not address health effects of exposure to SHS and merely requires posting a sign indicating whether smoking is unrestricted, permitted in specially ventilated areas, or smoke-free. The Charter also requires that establishments develop a written policy on smoking to be available for customers and staff. Ventilation is presented as the key element to comply with the Charter's requirements. ${ }^{127}$

The Public Places Charter, adopted as official government policy, was implemented in 1999 and remained official government policy in the UK as of late 2003, despite low compliance. ${ }^{128}$ The UK National Health Service was actively promoting the Public Places Charter until mid-2003, ${ }^{129}$ when it removed the promotional material from its brochures on passive smoking. ${ }^{130}$

The tobacco industry has a long history of sponsoringoften through third parties or front groups-studies which conclude that exposure to SHS is low. ${ }^{11}{ }^{14131}$ These studies need to be scrutinised carefully by public health authorities to make sure that they are indeed providing an accurate and complete picture of the exposures. For example, the Black Dog Pub study failed to report RSP levels in the smoking section, despite the fact that they were measured. Several hundred documents regarding the ventilation strategy have been added to tobacco industry web sites since the end of our search; the industry's ventilation strategy warrants continuous monitoring so that public health advocates, particularly in parts of the world where this strategy is new and where it is meeting with success, can continue to educate the public and policymakers about where the pressure for increasing ventilation rather than restricting smoking originates.

Despite the limited success of the ventilation strategy in the USA, the tobacco industry and its consultants have made, and continue to make, intense efforts to promote the tobacco industry's ventilation "solution". Public health advocates worldwide need to be vigilant to oppose compromises based on ventilation of smoking areas rather than smoke-free policies. The key argument is that, in the end, it is simpler, cheaper, and healthier to simply end indoor smoking.

\section{ACKNOWLEDGEMENTS}

This work was supported by National Cancer Institute Grants CA87472 and CA-61021.

\section{Authors' affiliations}

J Drope, S A Glantz, Center for Tobacco Control Research and Education, University of California, San Francisco, San Francisco, California, USA

S A Bialous, Tobacco Policy International, San Francisco, California, USA

\section{REFERENCES}

1 Fichtenberg CM, Glantz SA. Effect of smoke-free workplaces on smoking behaviour: systematic review. BMJ 2002;325:188.

2 Roper Organization. A study of public attitudes towards cigarette smoking and the tobacco industry. May 1978. legacy.library.ucsf.edu/tid/oci32fOO.

3 Anon. A review of and recommendations on passive smoking and social acceptability of smoking. Philip Morris; January 1976. legacy.library.ucsf.edu/tid/auc35e00.

4 Heironimus J. Impact of workplace restrictions on consumption and incidence. Philip Morris USA; 22 January 1992. Bates No. 2023914280/ 4284. legacy.library.ucsf.edu/tid/rvv24e00.

5 Anon. An action plan for ETS in Europe and adjacent areas, 1989-1992 Philip Morris; 10 August 1988. Bates No. 2501046476/6488. legacy.library.ucsf.edu/tid/sev32e00.

6 Dearlove J, Aguinaga Bialous S, Glantz S. Tobacco industry manipulation of the hospitality industry to maintain smoking in public places. Tobacco Control 2002; 11:94-104.

7 Drope J, Chapman S. Tobacco industry efforts at discrediting scientific knowledge of environmental tobacco smoke: a review of internal industry documents. J Epidemiol Community Health 2001;55:588-94.

8 Ong EK, Glantz SA. Constructing "sound science" and "good epidemiology": tobacco, lawyers, and public relations firms. Am J Public Health 2001;91:1749-57.

9 Ong EK, Glantz SA. Tobacco industry efforts subverting International Agency for Research on Cancer's second-hand smoke study. Lancet 2000;355:1253-9.

10 Barnes DE, Bero LA. Why review articles on the health effects of passive smoking reach different conclusions. JAMA 1998;279:1566-70.

11 Barnes DE, Bero LA. Industry-funded research and conflict of interest: an analysis of research sponsored by the tobacco industry through the Center for Indoor Air Research. J Health Polit Policy Law 1996;21:515-42.

12 Barnes DE, Hanauer P, Slade J, et al. Environmental tobacco smoke. The Brown and Williamson documents. JAMA 1995;274:248-53.

13 Bero LA, Galbraith A, Rennie D. Sponsored symposia on environmental tobacco smoke. JAMA 1994;271:612-7.

14 Barnoya J, Glantz S. Tobacco industry success in preventing regulation of secondhand smoke in Latin America: the Latin project. Tobacco Control 2002; 11:305-14.

15 Muggli M, Forster J, Hurt R, et al. The smoke you don't see: uncovering tobacco industry scientific strategies aimed against control of environmental tobacco smoke. Am J Public Health 2001;91:1419-93.

16 Muggli ME, Hurt RD, Blanke DD. Science for hire: a tobacco industry strategy to influence public opinion on secondhand smoke. Nicotine Tob Res 2003;5:303-14.

17 Winokur M. IAQ Projects. Philip Morris; 11 May 1990. Bates No. 2063577316/7317. legacy.library.ucsf.edu/tid/fqs67e00.

18 Anon. USA Ventilation program: current educational/development activities. Philip Morris 1998. Bates No. 2072264179/4180 legacy.library.ucsf.edu/ $\mathrm{tid} / \mathrm{kjiO6c00}$.

19 Anon. Ventilation Systems for Smoking Lounges. Philip Morris 1990. Bates No. 2063577304/7308 legacy.library.ucsf.edu/tid/bqs67e00.

20 Woods J. Comparative Evaluation of Displacement Ventilation and Conventional VAV Systems for Indoor Air Quality. Virginia Polytechnic 
Institute and State University; Januaryl, 1991. Bates No. 2050842764 legacy.library.ucsf.edu/tid/dep45e00.

21 Anon. IAQ Program 1993 Action Plan. Philip Morris 1992. Bates No. 2023054448. legacy.library.ucsf.edu/tid/kkz44e00.

22 Burnley HG. ETS - VPI Proposal for Demonstration of Displacement Room Ventilation. Philip Morris; October 16, 1990. Bates No. 2050952912/ 2913. legacy.library.ucsf.edu/tid/os $\times 09 \mathrm{e} 00$.

23 Anon. Science [Displacement Ventilation]. Philip Morris 1993. Bates No. 2025498651/8657. legacy.library.ucsf.edu/tid/dkz88e00.

24 Anon. FACT. Philp Morris1992. Bates No. 2024721177/1181. legacy.library.ucsf.edu/tid/kpk98e00.

25 Daragan K, Gongos L. The Caveman was Right. Philip Morris U.S.A. 4 December 1991. Bates No. 2054894724/4729. legacy.library.ucsf.edu/ $\mathrm{tid} / \mathrm{m} \times n 66 \mathrm{e} 00$.

26 Daragan K, Gongos L. F.A.C.T. air system could help prevent sick building syndrome. Philip Morris U.S.A.1991. Bates No. 2054894722/4723. legacy.library.ucsf.edu/tid//xn66e00.

27 Glantz SA, Balbach E. Tobacco war: inside the California battles. Berkeley: University of California Press, 1999.

28 US Department of Health and Human Services. The health consequences of involuntary smoking. A report of the Surgeon General, 1986. Rockville, Maryland: Public Health Service, Centers for Disease Control, 1986. (DHHS Publication No (CDC) 87-8398.)

29 Anon. Indoor air quality: alternative strategy. Philip Morris1986. Bates No. 2025818970. legacy.library.ucsf.edu/tid/syu23e00.

30 Robertson G. Sick building syndrome. ACVA Atlantic Inc.; 17 July 1985 Philip Morris. Bates No. 2021004300/4309. legacy.library.ucsf.edu/tid/ $\mathrm{mxl} 8 \mathrm{e} \mathrm{e} 00$.

31 Robertson G. Investigating the "sick building syndrome" ETS in context. ACVA Atlantic, Inc.; 14 January 1986 Philip Morris. Bates No. 2021005103/5125. legacy.library.ucsf.edu/tid/epj34e00.

32 Robertson G. Sick building syndrome. ACVA Atlantic Inc.; 11 August 1987 Philip Morris. Bates No. 2061692011/2012. legacy.library.ucsf.edu/tid/ pif49e00.

33 Anon. "My office makes me sick". Medical World News 9 September 1985.

34 Avedon D. Itinerary List of HBI Personnel for the Tobacco Institute Related Business During the Month of April, 1991. Tobacco Institute; 7 May 1991. Bates No. TIDN001 1867. legacy.library.ucsf.edu/tid/Isj91f00.

35 Anon. Healthy Buildings International. British American Tobacco Company Limited; January, 1993 Guilford Depository: Accessed 12 November $2001-23$ November 2001. Bates No. 500848566/8782. Volume 44 of 88 (UCSF).

36 Carlson SG. "Healthy Buildings-88" (HB-88). Philip Morris; 14 July 1988. Accessed 28 March 2002. Bates No. 2028364744/4746. legacy.library.ucsf.edu/tid/gyg56e00.

37 Avedon D. Scientific/Other Witness Appearance Requirements. Philip Morris; 14 December 1988. Bates No. 2501295002/5005. legacy.library.ucsf.edu/tid/swk29e00.

38 Huss D. Check, invoice, expenses [re:Fleishman Hillard Inc.]. Tobacco Institute; 30 May 1989. Bates No. TIDN0020081. legacy.library.ucsf.edu/ $\mathrm{tid} /$ thh91f0o.

39 Anon. Working Paper/ Merchandising ACVA/LINK Study/ Action Plan. Philip Morris; 20 September 1989. Bates No. 2028404047/4049. legacy.library.ucsf.edu/tid/erl56e00.

40 Anon. TI ETS/IAQ Consultant Activity: 1988-1990. Tobacco Institute 1990. legacy.library.ucsf.edu/tid/iill14d00.

41 Robertson G. October Services [re: $\mathrm{HBI}$ consulting services for TI]. The Tobacco Institute; 31 October 1991. Bates No. TIDN0025605/5612. legacy.library.ucsf.edu/tid/Hf9lfOO.

42 Anon. Public Smoking Programs of the Tobacco Institute. Tobacco Institute 1989. Bates No. TIDN0008739. legacy.library.ucsf.edu/tid/ nfl91 f00.

43 Avedon D. Itinerary List of HBI Personnel for the Tobacco Institute: Related Business During the Month of March, 1991. Tobacco Institute; 15 April 1991. Bates No. TIDN001 1870. legacy.library.ucsf.edu/tid/osj91fo0.

44 Packett K. Invoice for expenses for Simon Turner. Tobacco Institute; 26 February 1993. Bates No. TIDN0025629.

45 Healthy Buildings International Pty Ltd Indoor Environmental Consultants. 2002. http://www.hbi.com.au/whoarewe.html Accessed 28 November 2002.

46 Anon. Corporate Affairs Work Plan: Spain and Portugal. Philip Morris; May 1990. Bates No. 2501026750/6761. legacy.library.ucsf.edu/tid/ iav39e00.

47 Boyse S. Asian ETS Consultancy Programme. British-American Tobacco Company Limited; 25 March 1993. Bates No. 3005371 18/7172. Volume 20 of 88 (12 November 2001-23 November 2001).

48 PAHO. Profits over people: tobacco industry activities to market cigarettes and undermine public health in Latin America and the Caribbean. Washington: PAHO, 2002.

49 Assunta M, Fields N, Knight J, et al. "Care and feeding": the Asian ETS Consultants Program: School of Public Health, University of Sydney; 2002

50 Rupp J. Memorandum Re: Meetings in Quito Relating to ETS Consultants Program. Philip Morris; 23 November 1992. Bates No. 2023591380/ 1386. legacy.library.ucsf.edu/tid/jwf46e00.

51 Anon. Philip Morris International (Latin America). Philip Morris International; 25 March 1991. Bates No. 2503001929. legacy.library.ucsf.edu/tid/ gyp19e00.

52 Bermudez J. Indoor air quality in Latin America: US/European solutions may not be the answer. Healthy Buildings International. British American Tobacco Company 1993. Guildford Depository. Bates No. 500873959/3971.
53 Boyse S. Letter to Jorge Basso Dastugue [Re: HBI]. British American Tobacco Company; 29 June 1992. Guildford Depository. Bates No. 304058260/ 8263.

54 Raad J. Medio Ambiente, Un Reto En Latino America. Guildford Depository. Bates No. 500873803/3817.

55 Anon. Memo on revamping the HBI magazine. Tobacco Institute; 26 April 1991. Bates No. TIDN001 1756. legacy.library.ucsf.edu/tid/ cdk91foO.

56 Cammer P. BCIA Invoice. Business Council on Indoor Air; 6 February 1989. Bates No. TIDN0019909. legacy.library.ucsf.edu/tid/pth91 f00.

57 Anon. BCIA Board of Directors. Tobacco Institute. Bates No. TIDN0019909. legacy.library.ucsf.edu/tid/pth9lfoo.

58 Anon. Business Council on Indoor Air Legislative Affairs Work Group. Tobacco Institute; April 1991. Bates No. TIDN0022874. legacy.library.ucsf.edu/tid/kch91fo0.

59 Mintz M. Smoke screen. The Washington Post Magazine 24 March 1996:11-30.

60 American Nonsmokers' Rights Foundation. The Oak Ridge National Laboratory (ORNL) ties to the tobacco industry. Berkeley: ANR, 2003

61 Green C. ORNL study: next steps. Lorillard; 13 April 1995. R J Reynolds. Bates No. 89273021. legacy.library.ucsf.edu/tid/hiu20e00

62 Green C. TI-ETS Advisory Group Meeting-22 May 1986. RJ Reynolds; 6 June 1986. Bates No. 50664 7144/7150. legacy.library.ucsf.edu/tid/ piv44d00.

63 Rodgman A. Weekly Highlights Fundamental R\&D. RJ Reynolds; 19 June 1985. Bates No. 50652 8302/8304. legacy.library.ucsf.edu/tid//cb64d00.

64 Eisenberg M. Center for Indoor Air Research. RJ Reynolds; 15 May 1997. Bates No. 51757 8187/8188. legacy.library.ucsf.edu/tid/ecj82d00.

65 Eisenberg M. The Sapphire Group, Inc proposed work plan to CIAR. R J Reynolds; 3 January 1997 The Sapphire Group. Bates No. 51757 7893/ 7898. legacy.library.ucsf.edu/tid/ubj82d00.

66 Munger F. Oak Ridge to do smoke study: four-day monitoring to cover all types of indoor pollution. Knox News - Sentinel 13 February 2003.

67 Hirschhorn N, Aguinaga Bialous S, Shatenstein S. Philip Morris' new scientific initiative: An analysis. Tobacco Control 2001:10:247-52

68 Munger F. Funding won't influence results of secondhand smoke study, scientist says. Knoxville News-Sentinel 28 July 2003.

69 Jenkins R, Palausky A, Counts R, et al. Exposure to environmental tobacco smoke in sixteen cities in the United States determined by personal breathing zone air samples. J Expo Analy Environ Epidemiol 1998;6:472-502.

70 Anon. Philip Morris U.S.A. Scientific Affairs Issues and Opportunities. Philp Morris U.S.A.; 18 July. Bates No. 2059734340/4365. legacy.library.ucsf.edu/tid/byt18d00.

71 Hammond K. Exposure of U.S. workers to environmental tobacco smoke. Environmental Health Perspectives 1999:107(suppl 2):329-40.

72 Shopland D, Gerlach K, Burns D, et al. State-specific trends in smoke-free workplace policy coverage: the current population survey tobacco use supplement, 1993 to 1999. J Occup Environ Med 2001;43:680-6.

73 Gerlach K, Shopland D, Hurtman A, et al. Workplace smoking policies in the United States: results from a national survey of more than 100,000 workers. Tobacco Control 1997;6:199-206.

74 Bryan-Jones K, Bero L. Tobacco industry efforts to defeat the occupational safety and health administration indoor air quality rule. Am J Public Health 2003:93:585-92.

75 Center for Toxicology and Environmental Health. Toronto environmental tobacco smoke (ETS) air monitoring project. Philip Morris; 25 June 1999. Bates No. 2074407065/7148. legacy.library.ucsf.edu/tid/tir17d00.

76 Jenkins R, Finn D, Tomkins B, et al. Environmental tobacco smoke in the nonsmoking section of a restaurant: a case study. Regulatory Toxicology and Pharmacology 2001;34:313-20.

77 Repace J. Killer on the lose; 2003. http://www.ash.org.uk/html/ workplace/pdfs/killer.pdf Accessed 17 October 2003.

78 Guterman L. Scientists accuse toxicology journal of industry ties. The Chronicle 6 December 2002.

79 Canada Newswire. Ventilation solution given thumbs up: Ontario Hotel and Motel Association. http://www.newswire.ca/releases/May2001/15/ c4807.html; 2002,Accessed 20 November 2002.

80 Venmar. Ventilation blows away smoking in restaurants. http:// www.sheltersupply.com/faq/blackdogloungesmoke.pdf; 1999. Accessed 2002.

81 Canadian Restaurant and Foodservices Association. Environmental tobacco smoke in the non-smoking section of a restaurant: a case study. Web site summary; May 2001. http://www.crfa.ca/issues/ issues_smokingregulations_blackdog.htm Accessed 20 November 2002.

82 Canadian Restaurant and Foodservices Association. Restaurants caught in smoking crossfire; Accessed 2002.

83 Perley $M$. The hospitality industry, the tobacco industry and ventilation in Ontario. In: Interested Parties, ed. Toronto; 2002.

84 Libin K. Fuming mad in the Big Smoke. Canadian Business 2003.

85 Repace J. Verbatim and Minutes from Committee Meetings. In: Special Committee on Tobacco Control-Legislative Assembly of Saskatchewan. Regina, 2000.

86 Glantz S, Slade J, Bero L, et al. The cigarette papers. Berkley, Los Angeles, London: University of California Press, 1996.

87 NSRA. The Fraser Institute: economic think tank or front for the tobacco industry? Toronto: NSRA, 1999.

88 Dreyer L. Umbrella Grant to the IAQ Group at TDSA. Philip Morris; 10 November 1993. Shook, Hardy \& Bacon. Bates No. 2024699781/9782. legacy.library.ucsf.edu/tid/rcg02a00.

89 Anon. Transition year umbrella grant discussion. Philip Morris 1993. Bates No. 2024699783/9808. legacy.library.ucsf.edu/tid/ysj98e00. 
90 Sterling E, Sterling T. The impact of different ventilation levels and flourescent lighting types on building illness: an experimental study. Can J Public Health November/December, 1983 Philip Morris. Bates No. 2021006705/6712. legacy.library.ucsf.edu/tid/xhd33e00.

91 Sterling E, Sterling T, Dimichward H. Building illness in the white collar workplace. International Journal of Health, 1983 Philip Morris. legacy.library.ucsf.edu/tid/oxt23e00.

92 Sterling T. Economics and politics in the assessment of causes of building illness: the NAS/NRC report on indoor pollutants. International Journal of Health Services, 1984 Philip Morris. legacy.library.ucsf.edu/tid/nxt23e00.

93 Rosenbaum W, Sterling E. Estimating hospitality industry workers' exposure to health risks from environmental tobacco smoke under the hospitality industry of British Columbia's proposed indoor air quality ventilation plan Theodor D. Sterling and Associates, Ltd.; 29 October 1998. Philip Morris. Bates No. $2502212116 / 2183$ legacy.library.ucsf.edu/tid/gfy22d00.

94 Workers' Compensation Board of British Columbia. Public hearing on the proposed amendments to Part IV, Sections 4.82(3) and 4.83 of the Occupational Health and Safety Regulation [Environmental Tobacco Smoke]. In: Workers' Compensation Board of British Columbia, Richmond, BC, 2000.

95 Aguinaga Bialous S, Glantz S. ASHRAE Standard 62: The tobacco industry's attempt to create a national ventilation standard. Tobacco Control 2002;11:315-28.

96 Bialous SA, Yach D. Whose standard is it, anyway? How the tobacco industry determines the International Organization for Standardization (ISO) standards for tobacco and tobacco products. Tobacco Control 2001;10:96-104.

97 Lattanzio T. The increase of consumption restrictions worldwide. Philip Morris 1994. Bates No. 2025481952/1979. legacy.library.ucsf.edu/tid/ wcd95e00.

98 Philip Morris USA Options. www.pmoptions.com; 2002. Accessed November 2002.

99 Philip Morris USA. Public place smoking: reasonable ways to minimize secondhand smoke; 2003. http://www.philipmorrisusa.com/ policies_practices/public_place_smoking.asp.Accessed 28 October 2003.

100 American Nonsmokers' Rights Foundation. Ventilation Issues Update. In: 2000.

101 Anon. Strategic Technical Support (STS) For The Accomodation Program: 1993. Philip Morris 1993. Bates No. 2024104462/4467. legacy.library.ucsf.edu/tid/tba35e00.

102 Philip Morris USA Options. Ventilation options for IAQ in hospitality establishments. In: 22nd World Energy Engineering Congress; 1999.

103 Anon. Comments on OSHA Proposed IAQ Rule Prepared by the Chelsea Group, Ltd. Philip Morris; 12 August 1994. Bates No.2057835001.

104 TobaccoScam. Hired Guns: Chelsea Group: www.tobaccoscam.ucsf.edu; 2002. Accessed 2002

105 Demer L. Clear the air to aid smokers, pro-tobacco group suggests. Anchorage Daily News 2 March 2000; Sect. A1.

106 Anon. 1998 Accomplishments of Worldwide Scientific Affairs. Philip Morris USA 1998. Bates No. 2082868004/8008. legacy.library.ucsf.edu/tid/ tul65c00.

107 Lipowicz P. ETS/VTS Planning Process Phone Number. Philip Morris 18 January 1999. Bates No. 2502285875. legacy.library.ucsf.edu/tid/ piw22d00.

108 Lipowicz P. Proposal for formation of corporation to support indoor air research. Philip Morris; 11 March 1999. Bates No. 2063871374/1380. legacy.library.ucsf.edu/tid/xlq45d00.

109 Anon. 1999 Ventilation program: execution plan. Philip Morris; December 1998. Bates No. 2071781454/1489. legacy.library.ucsf.edu/ $\mathrm{tid} / \mathrm{rlu} 97 \mathrm{~d} 00$.

110 Stuntz S. 1988 Public smoking program: your memo of 2/12/88. Tobacco Institute; 5 March 1988: Accessed 27 March 2002. Bates No. TIDN0019193/9195.legacy.library.ucsf.edu/tid/enq91 f00.
111 Packett K. OSHA Request for Information. Tobacco Institute; 25 October 1991: Accessed 27 March 2002, Bates No. TIDN0025286/5288. legacy.library.ucsf.edu/tid/tbg91fo0.

112 Anon. Current activities: I. Scientific Community II. Other Audiences. Philip Morris 1991. Bates No. 2021 181794/1799. legacy.library.ucsf.edu/tid/ iiv32d00.

113 Caldeira S. RE: 2001 NRA Show Plan. Philip Morris; 16 January 2001. Bates No. 2080405495/5499. legacy.library.ucsf.edu/ $\mathrm{rid} / \mathrm{lru} 14 \mathrm{c} 00$.

114 Culley E. Letter from Options PM USA re: commitment to support of the Hospitality Coalition on Indoor Air Quality. Philip Morris USA 31 January 2000. Bates No. 2072395494. legacy.library.ucsf.edu/tid/ dop27d00.

115 Anon. Technical Committee Members. Philip Morris. Bates No. 2072395509. legacy.library.ucsf.edu/tid/pnp27d00.

116 Anon. ETS Strategy in the Philip Morris EEC Region. Philip Morris 1988. Bates No. 2028364722/4728. legacy.library.ucsf.edu/tid/iyg56e00.

117 Anon. Benedum Center Cafe MCP Project No. 88440 Outline Specification. Philip Morris; 5 March 1990. Bates No. 2050831629/1649. legacy.library.ucsf.edu/tid/siq42d00.

118 Burnley HG. Summary of 12/15/89 ETS Meeting [re: Benedum Center). Philip Morris; 19 December 1989. Bates No. 2057078481/8482. legacy. library.ucsf.edu/tid/iov52e00.

119 Anon. Comprehensive Public Smoking Program. Tobacco Institute; May 1988. Bates No. 2021549008/9028. legacy.library.ucsf.edu/tid/ bxf78e00.

120 Repace J, Kawachi I, Glantz S. Fact sheet on secondhand smoke. In: http:// www.repace.com/factsheet.html; 1999.

121 Repace J. Can ventilation control secondhand smoke in the hospitality industry? Repace Associates, Inc, 2000.

122 Anon. Presentation to Host Marriott Services. Philip Morris USA March 1999. Bates No. 2070753650/3709. legacy.library.ucsf.edu/tid/ bwz28d00.

123 Chapman S. "Can't stop the boy": Philip Morris' use of Healthy Building International to prevent workplace smoking bans in Australia. Tobacco Control 2003;12(suppl III):iii107-12.

124 Philip Morris. Worldwide Accomodation Program. 28 January 1998: Accessed 28 October 2003.http:// legacy.library.ucsf.edu/tid/pve04c00.

125 Hine K. Traditional hospitality. Good air good business. International Hotel and Restaurant Association: Accessed 28 October 2003. Bates No. 2085292167/2185. http://legacy.library.ucsf.edu/tid/usn10c00.

126 Philip Morris. Courtesy of choice \& traditional hospitality highlights for CEMA. Philip Morris; August 1998: Accessed 28 October 2003. Bates No. 2072594194/4198. http://legacy.library.ucsf.edu/tid/flf42c00.

127 Secretary of State for Health and the Secretaries of State for Scotland Wales and Northern Ireland. Smoking Kills-A White Paper on Tobacco. Chapter 7: Clean Air. London, England: The Stationary Office, 1998. Report No. CM4177

128 ASH UK. Smoking in Public Places, July 2003. http://www.ash.org.uk/ $\mathrm{html} /$ factsheets $/ \mathrm{html} /$ factl $4 . \mathrm{html}$ Accessed 18 October 2003.

129 UK National Health Service. Passive smoking: what it is and what you can do about it. London: Department of Health, 2002. (Order No. 50806B, DOH 02-9375)

130 UK National Health Service. Secondhand smoke: what it is and what you can do about it. London: Department of Health, 2003. (Order No. 5080A, DOH 258781)

131 Neilsen K, Glantz SA. A tobacco industry study of airline cabin air quality: dropping inconvenient findings. Tobacco Control 2004;13(suppl I): i20-9. 